always wrote with precision as well as elegance and verve, it was in conversation that one sensed how much he really knew.

\author{
A. J. S. REID \\ CRAIG J. REYNOLDS \\ The Australian National University
}

\title{
GORDON B. TURNER
}

Gordon B. Turner, 81, died May 13, 1996. Born in New York City, he settled in Princeton in 1946 where he resumed his undergraduate studies after a twelve-year hiatus spent in banking, brokerage, and the military-serving as an infantry captain on active duty in the Pacific during World War II. A member of Princeton University's Class of 1937, he received his B.A. degree in 1948 and his Ph.D. in 1950 and taught in the History Department until 1959, specializing in civil-military relations. He occupied the Ernest J. King Chair of Maritime History at the Naval War College during 1957-58, edited a History of Military Affairs Since the Eigbteenth Century, coedited and authored National Security in the Nuclear Age, and authored "The ACLS Committee on Studies of Chinese Civilization: A Review," ACLS Newsletter, 1971.

Dr. Turner joined the American Council of Learned Societies in 1959, serving as Executive Associate and Vice President, with primary responsibility for the Council's international studies programs (including in Asian Studies) until his retirement in 1980. He served on the Board of Trustees of the Center for Applied Linguistics and the Board of Directors of the Internarional Research and Exchanges Board, which he was responsible for establishing. He also served on the Secretary of the Navy's Advisory Committee on Naval History and on the U.S. National Commission for UNESCO.

Surviving are his wife, Jean Stewart Turner, his daughters, Michael Ann Walstad and Barbara Gazey Turner, his granddaughters Kimberly Elin and Catherine Avery Walstad, all of Princeton, N.J.; and his sister, Barbara F. Turner of Columbus, Ohio.

Arrangements are private. Contributions, including those of personal time, may be made to organizations that support death with dignity, such as the Hemlock Society U.S.A., P.O. Box 101810, Denver, Colo. 80250-1810; Americans for Death with Dignity, P.O. Box 11001, Glendale, Calif. 91226; Medical Center at Princeton Hospice, 253 Witherspoon Street, Princeton, N.J. 08540.

JEAN S. TURNER and FAMILY Princeton, N.J.

\section{A. RONALD WALTON}

$$
1943-1996
$$

A. Ronald Walton, professor of Chinese language and linguistics and experr in language pedagogy, policy, and planning, died of acute coronary thrombosis September 5, while visiting his mother in Austin, Texas. He was only 53. Dr. Walton had been a member of the University of Maryland faculty since 1983; he was also the Deputy Director of the National Foreign Language Center in Washington, D.C. 
Dr. Walton's professional range was unusual. After graduating from the University of Texas in 1967 with a degree in general linguistics, he took an M.A. and Ph.D. at Cornell in general and Chinese linguistics. He then began his academic career teaching Chinese language and linguistics with a research specialty in phonology and Chinese dialectology. He served as Deputy Director and Acting Director of the intensive Chinese language program at Cornell from 1972-75, then moved on to teach Chinese at the State University of New York at Albany, the University of Pennsylvania, and, in 1983, the University of Maryland. He completed two monographs on Chinese phonology: Phonological Redundancy in Shanghai (1976) and Tone, Segment and Syllable in Cbinese: A Polydimensional Approach to Surface Phonetic Structure (1983); both were published in the Cornell East Asia Papers Series.

In the early 1980s Walton's professional interests turned in a different direction. In quick succession he wrote a self-study guide to a widely used Japanese language text, then coauthored a three-volume text, A Course in Business Chinese. After that he began working as a consultant and reviewer of language programs and curricula, not only in Chinese but other languages as well, and in this capacity he quickly made a name for himself as one of the best in the business.

At the time of his death, Walton had reviewed more language programs and advised more organizations on language-related issues than perhaps anyone in the world.

In 1987 Walton helped found the National Foreign Language Center in Washington, D.C., serving as its Deputy Director from that time until his death. It was in this capacity that Walton made his greatest contributions to national language policy and standards for foreign language education. Working with ACTFL, the Department of Education, the College Board, and other organizations, he helped develop national standards for French, German, Spanish, Hebrew, Chinese, Japanese, and Korean.

As Co-Director of the National Council of Organizations of Less Commonly Taught Languages, he was instrumental in establishing national teacher organizations for African, South Asian, and Southeast Asian languages, and Korean. He wrote two monographs and ten articles on language assessment, policy, and standards; he lectured on almost a daily basis on these topics. He was the principal investigator, or coprincipal investigator, for at least fifteen major grants shaping a new vision for language in America. At the same time, however, Walton remained committed to his original interest, Chinese language education; he was under contract with Yale University to develop a new elementary Chinese textbook.

Dr. Walton also remained a committed member of the University of Maryland faculty. He was instrumental in the establishment of the Language Center and served as its Director from 1991-93. In the Department of Asian and East European Languages and Cultures, where he taught half-time, he dedicated himself to shaping the language curriculum into forms to meet the needs of the twenty-first century, and to developing M.A. programs for training language-teaching professionals who would understand and respond to those needs.

S. ROBERT RAMSEY University of Maryland 